$$
\begin{aligned}
& \text { ANL/CMT/CP-93028 } \\
& \text { CONF-970902 - }
\end{aligned}
$$

\title{
Retention of Neptunium in Uranyl Alteration Phases formed during Spent Fuel Corrosion
}

\author{
E. C. Buck, R. J. Finch, P. A. Finn, and J. K. Bates
}

Chemical Technology Division

Argonne National Laboratory

9700 South Cass Avenue

Argonne IL 60439-4837

The submitted manuscript has been authored by a

contractor of the U.S. Government under contract No.

W-31-109-ENG-38. Accordingly, the U.S. Government

retains a nonexclusive, royalty-free license to publish

or reproduce the published form of this contribution, or

allow others to do so, for U.S. Government purposes.

Submitted for consideration in

Scientific Basis for Nuclear Waste Management XXI

Davos, Switzerland

August 1997

* This work was performed under guidance of the Yucca Mountain Site Characterization Project (YMP) and is part of activity D-20-43 in the YMP/ Lawrence Livermore National Laboratory Spent Fuel Scientific Investigation Plan. Work supported by the U.S. Department of Energy under contract W-31-109-ENG-38.

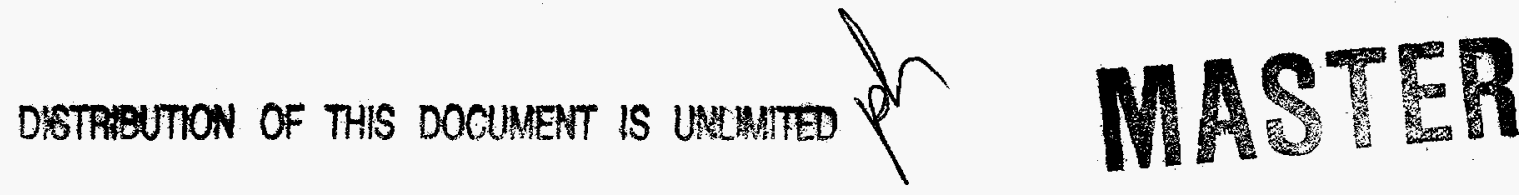




\section{DISCLAIMER}

This repor was prepared as an account of work sponsored by an agency of the United States Government. Neither the United States Government nor any agency thereof, nor any of their employees, makes any warranty, express or implied, or assumes any legal liability or responsibility for the accuracy, completeness, or usefulness of any information, apparatus, product, or process disclosed, or represents that its use would not infringe privately owned rights. Reference herein to any specific commercial product, process, or service by trade name, trademark, manufacturer, or otherwise does not necessarily constitute or imply its endorsement, recommendation, or favoring by the United States Government or any agency thereof. The views and opinions of authors expressed herein do not necessarily state or reflect those of the United States Government or any agency thereof. 


\section{DIschamisR}

Portions of this document may be illegible in electronic image prodnets. Images are produced from the best available osiginal cosmonert 


\title{
RETENTION OF NEPTUNIUM IN URANYL ALTERATION PHASES FORMED DURING SPENT FUEL CORROSION
}

\author{
E. C. BUCK, R. J. FINCH, P. A. FINN, AND J. K. BATES
}

Argonne National Laboratory, Argonne, IL 60439

\begin{abstract}
Uranyl oxide hydrate phases are known to form during contact of oxide spent nuclear fuel with water under oxidizing conditions; however, less is known about the fate of fission and neutron capture products during this alteration. We describe, for the first time, evidence that neptunium can become incorporated into the uranyl secondary phase, dehydrated schoepite $\left(\mathrm{UO}_{3} \cdot 0.8 \mathrm{H}_{2} \mathrm{O}\right)$. Based on the long-term durability of natural schoepite, the retention of neptunium in this alteration phase may be significant during spent fuel corrosion in an unsaturated geologic repository.
\end{abstract}

\section{INTRODUCTION}

Owing to its long half-life and alpha activity, $\mathrm{Np}^{237}$ is considered to be one of the most important radionuclides to be immobilized in a geologic repository [1]. As both carbonate and hydroxide strongly complex $\mathrm{Np}$ ions in solution, it has been presumed that these forms of $\mathrm{Np}$ will most likely control the release of $\mathrm{Np}$ from a geologic repository [2]. We report evidence that $\mathrm{Np}$ may become incorporated into dehydrated schoepite during the corrosion of spent nuclear oxide fuel under some repository-relevant conditions.

Uranium dioxide readily alters to a series of uranyl oxide hydrates and uranyl silicates when exposed to oxidizing conditions in silica-bearing solutions [3]. However, under conditions expected at the proposed geologic repository at Yucca Mountain in Nevada, spent fuel is anticipated to be contacted only with water vapor and/or small amounts of dripping water. As the fuel is exposed to water vapor, a surface corrosion rind may form, consisting of uranyl oxide hydrates and depending on the species present in the groundwater, in the presence of dripping water, uranyl -silicates, -carbonates, and -phosphate may also eventually form [3,4]. A similar paragenesis has been observed at many weathered natural uraninite $\left(\mathrm{UO}_{2}\right)$ deposits, such as at Shinkolobwe in the Congo and Peña Blanca in Mexico [4,5].

The behavior of the fission and neutron capture products, during the anticipated corrosion of spent nuclear fuel in an oxidizing environment is important for determining the long-term release rates of radionuclides. Using a unique anion topology approach for comparing the structures of uranyl phases, Burns et al. [6] have predicted mechanisms by which transuranic species could be incorporated into the alteration products of corroded spent fuel. As the U-O bond length $(0.18 \mathrm{~nm})$ in the linear species $\mathrm{UO}_{2}^{2+}$ is similar to that of $\mathrm{Np}-\mathrm{O}$ in $\mathrm{NpO}_{2}^{+}(0.165-0.181 \mathrm{~nm})$ and when coordinated by $\mathrm{O}^{2-}, \mathrm{OH}^{2}$, or $\mathrm{H}_{2} \mathrm{O}$, the equatorial $\mathrm{Np}-\mathrm{O}$ bond distances are only about $0.01 \mathrm{~nm}$ longer than those found in similarly coordinated uranyl polyhedra, it is reasonable to expect isomorphic substitution of the neptonyl ion in uranyl ion sites [6]. However, owing to valence bonding considerations, the axial oxygens on the linear neptonyl species may require additional valence contributions from interlayer cations or protons in the uranyl phase.

\section{EXPERIMENTAL PROCEDURE}

Two types of unsaturated tests are discussed in this paper. The first involves exposing Approved Testing Material (ATM) 103 [7] to water vapor held at $90^{\circ} \mathrm{C}$. The ATM103 is a single pin spent nuclear fuel of moderate burn-up ( $33 \mathrm{MWd} / \mathrm{kgM})$ from the Calvert Cliffs pressurized water reactor, which exhibits low fission gas release $(0.25 \%)$. Under these conditions the fuel pellets were exposed to a thin film of water. In the other type of tests, termed "high-drip", about $0.75 \mathrm{~mL}$ of EJ-13 water is dripped onto the ATM103 fuel package every 3.5 days [8]. The EJ-13 water is a tuff rock-equilibrated groundwater from the J-13 bore-hole near Yucca Mountain. Air is also injected into the test vessel with the water. The waste package design consists of fuel pellets placed on a Zircaloy retainer which has holes to allow the passage of water into a steel collection 
vessel which is positioned below. The high-drip tests have been in continuous operation for nearly 5 years. Periodically, the collection vessel is removed, and the liquid solution contents analyzed. Another clean collection vessel is then attached to the experimental setup, and the test is continued. The solid samples were taken from the fuel pellets on the Zircaloy retainer. The corrosion products that developed on these spent fuel fragments were examined with optical and scanning electron microscopy (SEM).

Representative particles of the corroded fuel were embedded in an epoxy resin, and thinsectioned with an ultramicrotome. The resultant 30-50 nm electron-transparent cross-sections of corroded fuel grains were transferred to carbon-coated copper grids and examined in a JEOL 2000 FXII analytical transmission electron microscope (AEM) operated at $200 \mathrm{kV}$ with a LaB filament. $^{2}$ The AEM is equipped with a Gatan 666 parallel electron energy-loss spectrometer, which has an energy resolution of about 1.6-1.8 eV. The actinide M-edges were obtained by operating the spectrometer in the second-difference mode [9]. This technique removes the channel-to-channel gain variation that occurs with parallel detectors. The method also acts as a frequency filter, enhancing the sharp features such as the "white-lines" on the absorption edges. Hence, peak shape will effect the ability to detect an element. A smooth edge, for instance, will be less visible than a sharp edge. Electron diffraction patterns were taken with a charged coupled device (CCD) camera which permits very low intensity viewing and, therefore, is ideal for electron beam-sensitive materials.

\section{RESULTS}

In this section, the results from the analysis of the solid uranium-bearing phases from both the vapor and high-drip rate tests are presented. Before discussing these data, the technique of energy-loss spectroscopy (EELS) and how it pertains to the detection of transuranics will be addressed. In EELS the shape and intensity of an elemental absorption edge depends on that its electron cross-section and chemical state. Hence, the technique can be used to determine the local chemical environment. Compared to X-ray absorption spectroscopy, EELS utilizes much lower energy absorption edges. Edges in the range from $50 \mathrm{eV}$ up to $1900 \mathrm{eV}$ are most commonly investigated; however, in this work, the edges obtained were at an exceptionally high energy-loss range (3500-4500 eV) for a transmission electron microscope. Longer counting times (or integration times) were required, typically $2-5 \mathrm{~s}$, at each energy offset, higher beam intensities, and a large number of continuous acquisitions (typically 20-50). For the second-derivative technique, the derivative is calculated from three spectra taken at slightly different energy offsets $(1-6 \mathrm{eV})$, and then the derivative of these three spectra is calculated. This resulted in a total analysis time of 120 $750 \mathrm{~s}$. These conditions necessarily cause immediate amorphization of the uranyl phases but, we believe, not vaporization. Energy-loss analysis with AEM, of course, has much better spatial resolution than $\mathrm{X}$-ray spectroscopic methods.

\section{Low Level Detection of Transuranics}

For the detection of fission products and transuranic elements present in spent fuel and its alteration products, EELS has proven to be extremely effective. In Fig. 1, EELS from an uncorroded sample of spent fuel are shown. The major component, uranium, is visible in the two energy-loss ranges presented. In the lower energy range (Fig. 1a), the uranium $N_{4,5}$ edges at 738 $\mathrm{eV}$ and $780 \mathrm{eV}$, along with a number of rare earths, are visible. The transuranic $\mathrm{N}$-edges overlap strongly with the rare earths, and as they are weak features in this energy range, they can not be detected. However, in the high energy-loss range (Fig. 1b), the transuranic M-edges are clearly visible. The sharp absorption edge features in Fig. 1b, correspond to the two electronic transitions, $3 d_{3 / 2} \rightarrow 5 f_{5 / 2}\left(\mathrm{M}_{5}\right)$ and $3 d_{5 / 2} \rightarrow 5 f_{7 / 2}\left(\mathrm{M}_{4}\right)$, of the transuranics, that arise from spin-orbit splitting. Owing to the interference with the large number of other elements present in the fuel and in its corrosion products, this high energy-loss range is the only region where the transuranics can be detected with confidence [10]. The higher energy transuranic L- and K-edges are beyond the capabilities of the system. 
a

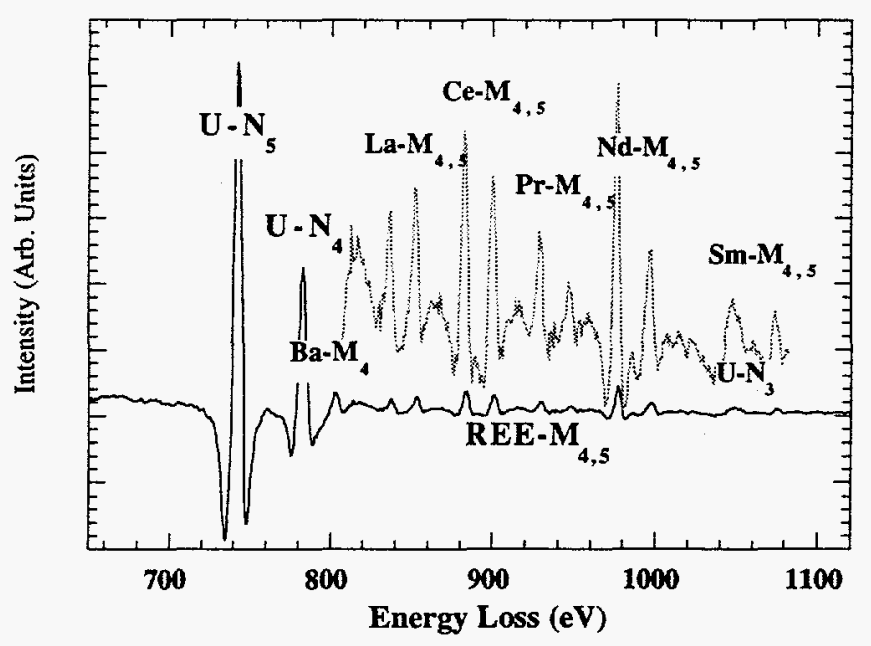

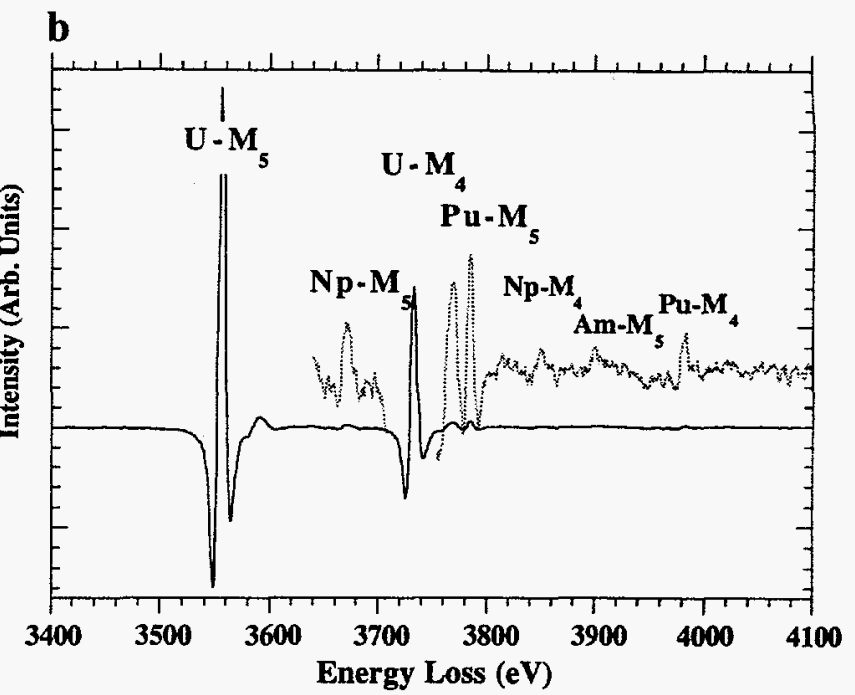

Fig. 1 Second-difference EELS of uncorroded spent fuel. In (a) the rare earth element $\mathbf{M}_{4,5}$ edges of $\mathrm{La}, \mathrm{Ce}, \mathrm{Pr}, \mathrm{Nd}$, and $\mathrm{Sm}$ are visible. The scale has been expanded $10 \mathrm{x}$ so that the rare earths are more clearly visible. In (b) the $U-M_{4.5}$ edges at $3552 \mathrm{eV}\left(\mathrm{M}_{5}\right)$ and $3728 \mathrm{eV}\left(\mathrm{M}_{4}\right)$, as well as the transuranic elements; $\mathrm{Np}\left(\mathrm{M}_{5}=3666 \mathrm{eV}\right.$ and $\mathrm{M}_{4}=3850 \mathrm{eV}, \mathrm{Pu}\left(\mathrm{M}_{5}=3778 \mathrm{eV}, \mathbf{M}_{4}=3973 \mathrm{eV}\right)$, and Am $\left(M_{5}=3887 \mathrm{eV}, M_{4}=4092 \mathrm{eV}\right)$ have been detected. The scale has been expanded $20 \mathrm{x}$ so that the transuranic edges can be seen.

\section{Characterization of Alteration Products from Vapor Phase Tests}

Examination of the corroded fuel with SEM demonstrated the presence of characteristic "boat-shaped" crystals of dehydrated schoepite $\left[\left(\mathrm{UO}_{2}\right) \cdot 0.8 \mathrm{H}_{2} \mathrm{O}\right]$ (see Fig. 2a). The presence of dehydrated schoepite was confirmed with electron diffraction in the AEM. In Fig $2 b$, a singlecrystal pattern of this alteration phase, and Table 1 lists the diffraction spacings obtained from a series of polycrystalline patterns, which support the phase identification.

a

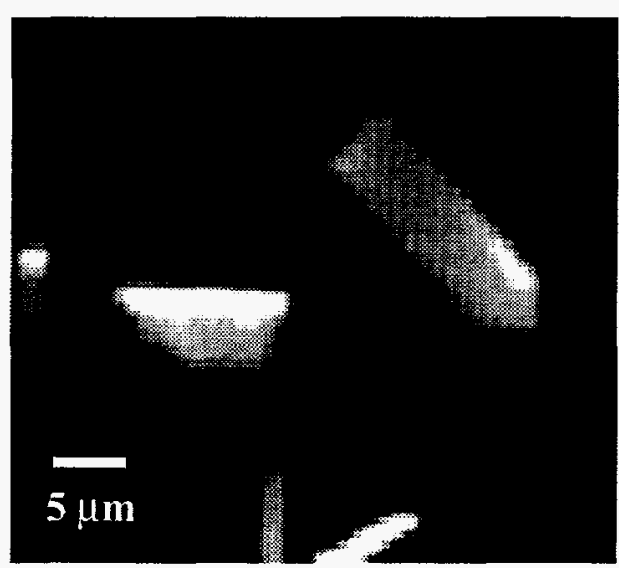

b

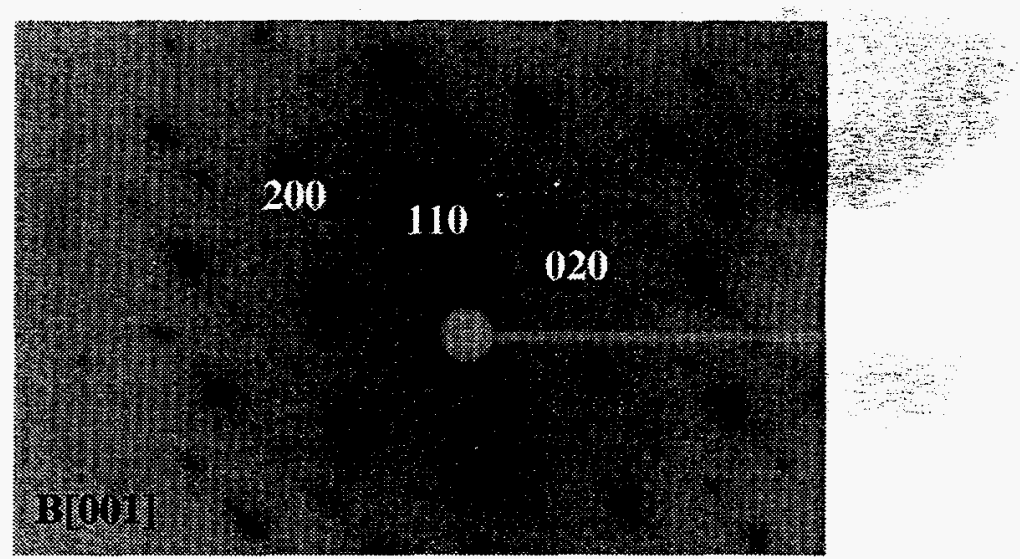

Fig. 2a. The SEM image of the uranyl phase shows the characteristic shaped crystals indicative of dehydrated schoepite. (b) The computer simulations of dehydrated schoepite agreed with the experimentally obtained CCD electron diffraction pattern from the uranyl oxide phase shown above. 
Table 1. Measured electron diffraction parameters from the major spent fuel alteration phase in vapor-reacted sample compared to literature $\mathrm{X}$-ray diffraction values of dehydrated schoepite.

\begin{tabular}{c|c}
\hline $\mathrm{d}_{\mathrm{obs}}(\mathrm{nm})$ & $\mathrm{d}_{\mathrm{lit}}(\mathrm{nm})(\mathrm{hkl})$ \\
\hline Spent Fuel Alteration Phase & Dehydrated Schoepite \\
\hline $0.7023^{3}$ & $0.511(200)$ \\
$0.5206,0.5242$ & \\
0.3631 & $0.345(111), 0.343(020)$ \\
$0.351,0.3462$ & $0.286(220)$ \\
0.2978 & \\
0.2908 & \\
0.2697 & \\
0.2630 & $0.249(311)$ \\
0.2612 & $0.214(002)$ \\
$0.2567,0.2532$ & \\
0.2189 & $0.205(420)$ \\
0.2045 & $0.182(022)$ \\
$0.1861,0.1856$ & $0.171(222)$ \\
0.1692 & $0.148(422)$ \\
0.1471 & \\
\hline
\end{tabular}

${ }^{1}$ Values are an average of several d-spacings from a number of diffraction patterns. Errors in d-spacings are $\pm 2.5 \%$.

${ }^{2}$ Unit cell parameters are $\mathbf{a}=0.686 \mathrm{~nm}, \mathbf{b}=0.426 \mathrm{~nm}$, and $\mathbf{c}=1.020 \mathrm{~nm}$ [11].

${ }^{3}$ Reflection only seen in a few patterns. It was lost rapidly during observation.

The only other alteration phase found on the vapor-reacted sample was a Cs-Mo uranyl oxide hydrate. The composition of this phase matched with that previously reported in high-drip tests with ATM106 spent fuel after 0.8 years of reaction, where the ideal composition of this phase was estimated to be $\left(\mathrm{Cs}_{0.90} \mathrm{Ba}_{0.55}\right)\left(\mathrm{UO}_{2}\right)_{5}\left(\mathrm{MoO}_{2}\right) \mathrm{O}_{4}(\mathrm{OH})_{6} \cdot 6 \mathrm{H}_{2} \mathrm{O}$ [12]. These Cs-Mo uranyl particles were 100-200 $\mathrm{nm}$ in length, but no structural information was obtained from them (see Fig. 3).

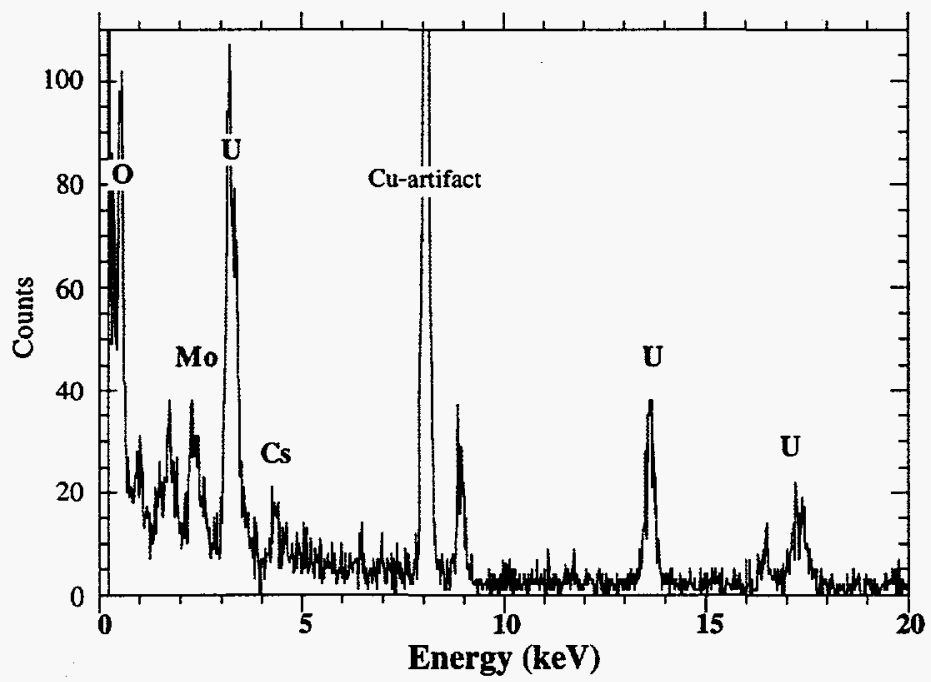

Fig. 3 X-ray energy dispersive spectrum of a Cs-Mo uranyl oxide hydrate. Both the dehydrated schoepite and this Cs-bearing phase were observed on the reacted fuel surfaces. 
Energy-Loss Analysis of Dehydrated Schoepite from Vapor Phase Tests

Analysis of the dehydrated schoepite phase with EELS indicated the presence of Np (Fig. 4). Since we examined cross-sections of the corroded fuel grains and alteration products, it is unlikely that the occurrence of $\mathrm{Np}$ was due to sorption on the dehydrated schoepite; however, we cannot exclude this mechanism for retention of $\mathrm{Np}$ in an alteration phase. Neptunium was observed with EELS in three samples of dehydrated schoepite which were taken from different regions of the corroded fuel pellets.

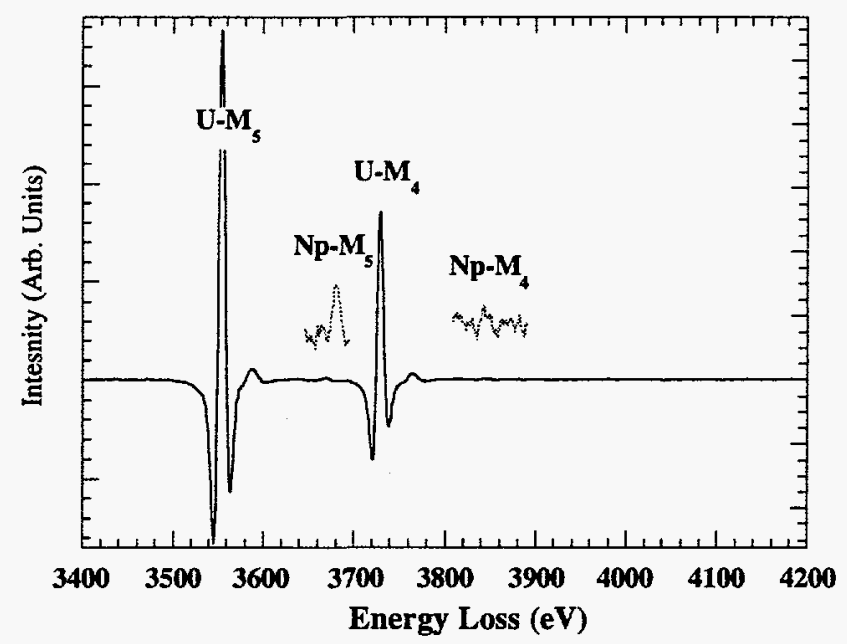

Fig. 4. Electron energy-loss spectrum of dehydrated schoepite showing the presence of $\mathrm{Np}$ in the phase. The two intense uranium edges $\left(\mathrm{M}_{5}\right.$ at $3552 \mathrm{eV}$ and $\mathrm{U}-\mathrm{M}_{4}$ at $\left.3728 \mathrm{eV}\right)$ dominate the spectrum; however, the $\mathrm{Np}-\mathrm{M}_{5}$ edge at $3666 \mathrm{eV}$ is clearly visible. The intensity of the $\mathrm{Np}$ edges has been increased $20 \mathrm{x}$ for easier viewing. The $\mathrm{Np}-\mathrm{M}_{4}$ edge at $3850 \mathrm{eV}$ does not appear to be visible above the background.

The U:Np ratio was estimated to be between 1:0.003 and 1:0.006, based on five analyses. In the dehydrated schoepite $\left(\mathrm{UO}_{3} \cdot 0.8 \mathrm{H}_{2} \mathrm{O}\right)$ where $\mathrm{Np}$ was detected, this ratio corresponds to one $\mathrm{Np}$ atom for every 250 unit cells of $\mathrm{UO}_{3} \cdot 0.8 \mathrm{H}_{2} \mathrm{O}$ or about $550 \mathrm{ppm}$. The U:Np ratio in the ATM103 fuel is 1:0.0005, taken from calculated values reported by Guenther et al. [7] for ATM 103 at $35 \mathrm{MWd} / \mathrm{kgM}$ after 15 years. The estimated U:Np ratio in the alteration phase indicates that a large proportion of the $\mathrm{Np}$ has entered into the phase. Owing to the scarcity of water under the testing conditions, little, if any, water was able to flow into the steel collection vessel positioned at the bottom of the test apparatus. Under these conditions, it might be expected that the highly soluble elements will become concentrated enough in the thin-film of water to precipitate secondary phases. The absence of Pu and Am in the dehydrated schoepite supports the contention that only $\mathrm{Np}$ and $\mathrm{U}$ were mobilized during the corrosion process and incorporated into a secondary phase.

Under more dynamic conditions, where flowing water was present, the retention of the $\mathrm{Np}$ in alteration phases may not occur. The next section presents similar EELS analysis of uraniumbearing alteration phases formed under relatively high flow conditions.

\section{Electron Energy-Loss Analysis of Uranium Silicate Alteration Phases from High Drip Tests}

In the related high-drip tests, the analysis of the corrosion products failed to indicate the presence of $\mathrm{Np}$ at the same level observed in the vapor tests. In Fig. 5, the EDS and electron diffraction analysis suggested that this corrosion product was related to $\beta$-uranophane (ideally $\left.\mathrm{Ca}\left[\left(\mathrm{UO}_{2}\right)\left(\mathrm{SiO}_{3} \mathrm{OH}\right)\right]_{2} \cdot 5 \mathrm{H}_{2} \mathrm{O}\right)$. A trace amount of ruthenium was present in the phase and this can also be seen in the energy-loss spectrum (see Fig. 5c). The form of the uranyl alteration phases is dependent on the composition of the fluid in contact with the fuel. In the high-drip tests, the fuel is contacted by silica-saturated EJ-13; hence, uranyl silicates are the dominant alteration products. 
$\mathbf{a}$

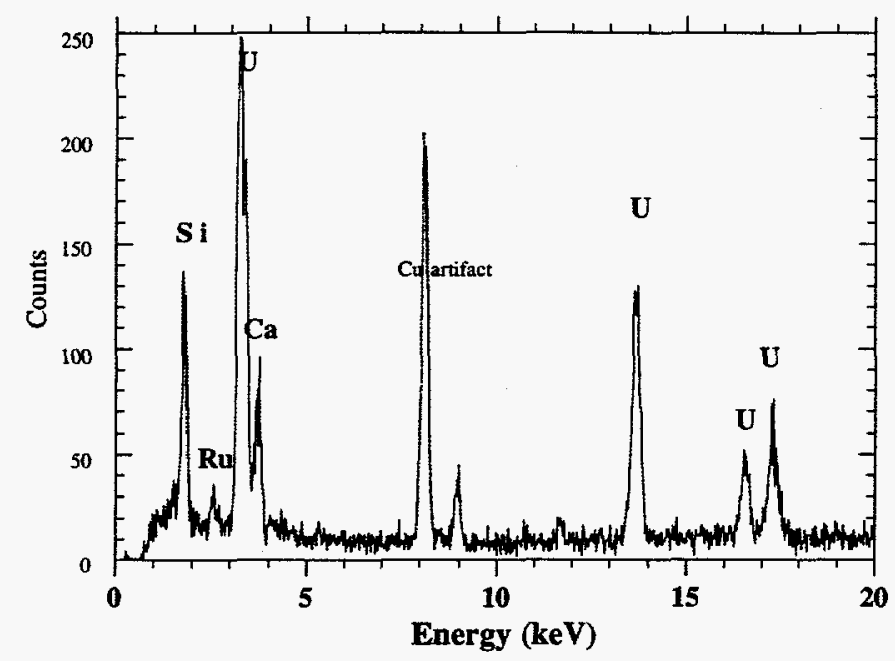

b

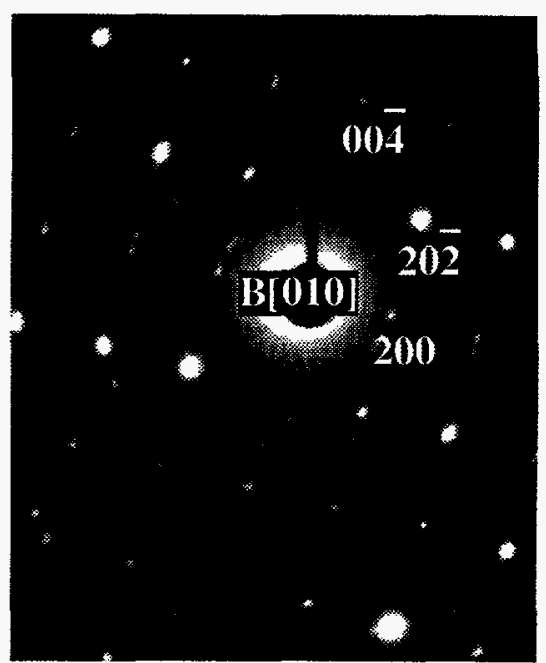

Fig. 5 (a) X-ray energy-dispersive spectrum of an alteration phase from a high drip rate test reacted for 44 months. In (b) an electron diffraction pattern taken along [010] from the uranyl silicate phase is shown. A $\beta$-angle of about $93^{\circ}$ was obtained from the analysis of the patterns.

c

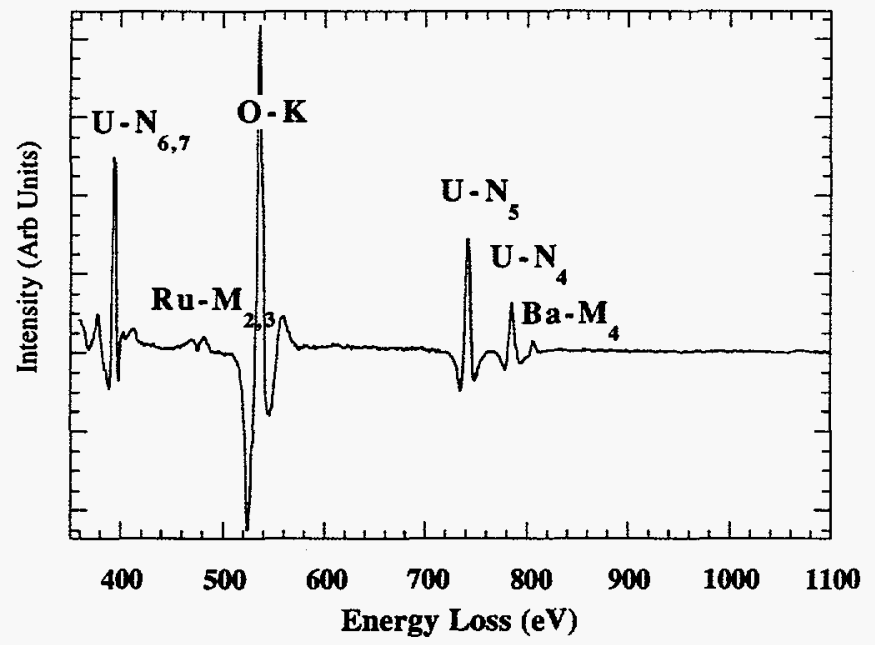

d

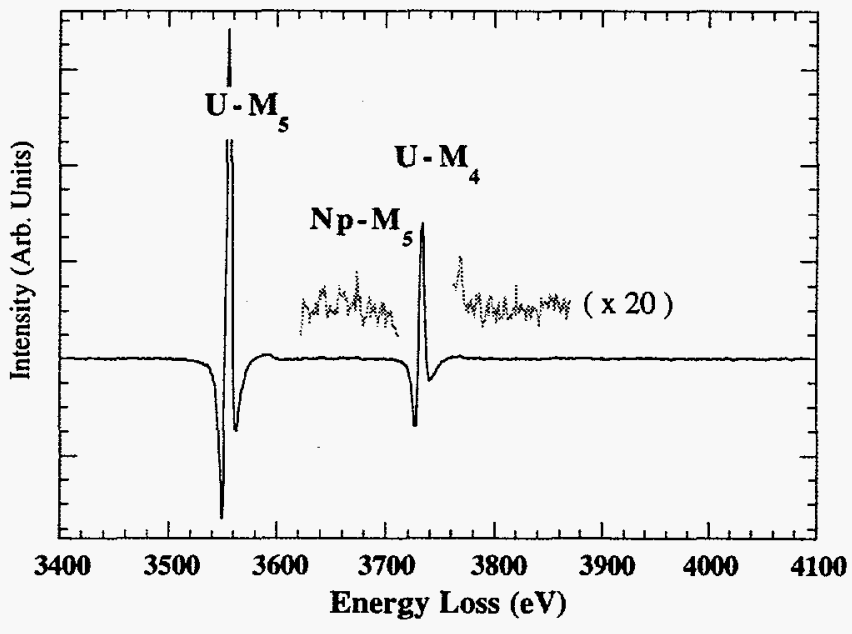

Fig. 5 (c) Electron energy-loss spectrum of uranyl silicate alteration phase from the high-drip test, showing the U-N edges and (d) spectrum showing the high energy-loss M-edges of uranium.

There may be a suggestion of some $\mathrm{Np}$ in uranyl silicate phase; however the levels are at, or below, the detection limits for the instrument. The estimated U:Np ratio is not more than 1:0.0005, which corresponds to $<50 \mathrm{ppm} \mathrm{Np}$ in the phase, which appears to be the detection limit.

\section{DISCUSSION}

Substitutions of the type $\mathrm{Np}^{5+}<->\mathrm{U}^{6+}$ may occur in all uranyl structures [6]; however, evidence from the majority of solution analyses from waste form testing suggests that $\mathrm{Np}$ remains stable as complexes in solution under most common pH-Eh regimes. Nevertheless, within the 
thin-film of water in contact with the spent nuclear fuel, significant alpha radiolysis will occur, leading to the possible formation of $\mathrm{H}_{2} \mathrm{O}_{2}$. The altered Eh conditions may result in changes in the $\mathrm{Np}$ chemistry which may favor incorporation into the uranyl sheets. These sheets may be easily charge balanced through substitutions of the type $\mathrm{O}^{2-}<->\mathrm{OH}^{-}$. The most common oxidation state for $\mathrm{Np}$ in oxygen-rich waters is $\mathrm{Np}(\mathrm{V})$. In the vapor tests, because the $\mathrm{pH}$ of the contacting solution is unknown, it may be speculative to describe the form of the $\mathrm{Np}$. However, calculations suggest that in a J-13 Yucca Mountain groundwater above $\mathrm{pH} 7.5$, the dominant species is $\mathrm{NpO}_{2}\left(\mathrm{CO}_{3}\right)^{-}$and $\mathrm{NpO}_{2}^{+}$below this $\mathrm{pH}[2]$. The $\mathrm{pH}$ of the contacting solution in the high drip tests is known to be about 6 [8], suggesting that $\mathrm{NpO}_{2}^{+}$will be the most prominent species.

The incorporation of transuranics into the alteration products of oxide spent fuel corrosion has been predicted on crystal chemical considerations [6]; although, it has seldom been observed. This may be due, in part, to the limitations of instrumental techniques and the difficulty in working with transuranic-bearing samples; however, knowledge of the specific conditions required for substitution of particular radionuclides into alteration phases may lead to development of engineered systems that may retard the migration of these radionuclides.

The observation of $\mathrm{Np}$ incorporation into dehydrated schoepite was only possible by examining thin sections of the reacted material with EELS. This technique has excellent detection capabilities and spatial resolution to locate regions where transuranics have been concentrated. Although, the limits of detection for EELS are essentially a function of the analysis time and beam intensity; when using the second-difference method, peak shape is also important. Future improvements in detection limits should be possible with the use of an energy-loss imaging filter which, when operated as a two-dimensional array spectrometer, is much more efficient than the parallel detector used in this study.

\section{CONCLUSIONS}

We have demonstrated that the release of $\mathrm{Np}$ may be controlled by uranyl alteration phases formed during the corrosion of oxide spent nuclear fuel in an unsaturated environment. Although schoepite is only a transient phase in paragenesis of uraninite, Finch et al. [13] have demonstrated that the schoepite at weathered uraninite deposit at Shinkolobwe has lasted over 250,000 years. Indeed, at the same site the uranyl carbonate, rutherfordine $\left[\mathrm{UO}_{2}\left(\mathrm{CO}_{3}\right)\right]$, exhibited exceptional persistence. This suggests that the retention of $\mathrm{Np}$ in dehydrated schoepite during vapor phase corrosion, may not be ephemeral. Consequently, this noteworthy observation of $\mathrm{Np}$ in dehydrated schoepite may provide evidence to reduce the impact of $\mathrm{Np}$ migration on the present performance assessment calculations for the Yucca Mountain repository.

\section{ACKNOWLEDGMENTS}

This work was performed under guidance of the Yucca Mountain Site Characterization Project (YMP) and is part of activity D-20-43 in the YMP/ Lawrence Livermore National Laboratory Spent Fuel Scientific Investigation Plan. Work supported by the U.S. Department of Energy under contract W-31-109-ENG-38.

\section{REFERENCES}

1. I. R. Triay, B. A. Robinson, A. J. Mitchell, C. M. Overly, and R. M. Lopez, Mater. Res. Soc. Symp. Proc. 294, 797 (1993).

2. D. L. Clark, D. E. Hobart, and M. P. Neu, Chem. Rev. 95, 25-48 (1995).

3. D. J. Wronkiewicz, J. K. Bates, S. F. Wolf, and E. C. Buck, J. Nucl. Mater. 238, 78 (1996).

4. R. J. Finch and R. C. Ewing, J. Nucl. Mater. 190, 133 (1992).

5. E. C. Pearcy, J. D. Prikryl, W. M. Murphy, and B. W. Leslie, Appl. Geochem. 9, 713 (1994).

6. P. C. Burns, R. C. Ewing, and M. L. Miller J. Nucl. Mater. 245, 1 (1997). 
7. L. E. Thomas and R. J. Guenther, Mater. Res. Soc. Symp. Proc. 127, 293 (1989); R. J. Guenther et al., Characterization of Spent Fuel Approved Testing Material-ATM-103, Pacific Northwest Laboratory Report, PNL-5109-103 (1988).

8. P. A. Finn, E. C. Buck, J. C. Hoh, and J. K. Bates, Global 1995, Inter. Conf. Eval. Emerging Nucl. Fuel Cycle Syst., 241 (1995).

9. R. D. Leapmann, and D. E. Newbury, Anal. Chem. 65, 2409 (1993).

10. E. C. Buck and J. A. Fortner, Ultramicro. 67, 69-77 (1997).

11. R. J. Finch, and R. C. Ewing, Mater. Res. Soc. Symp. Proc. 333, 625-630 (1994).

12. E. C. Buck, D. J. Wronkiewicz, P. A. Finn, and J. K. Bates, J. Nucl. Mater. (1997)

13. R. J. Finch, J. Suksi, K. Rasilaninen, and R. C. Ewing, Mater. Res. Soc. Symp. Proc. 412,823 (1996). 